\title{
Psychological Contract Sebagai Alternatif dalam Meninjau Pemenuhan Harapan Akademik di Perguruan Tinggi
}

\author{
Rezki Ashriyana S. \\ E-mail : rezki.ashriyana@gmail.com
}

Fakultas Psikologi, Universitas Padjadjaran

Jl. Raya Bandung- Sumedang Km 21, Jatinangor - Sumedang 43363.

\begin{abstract}
Abtract
Higher education, as an institution that generates the nation's next future leader are no longer burdened with merely providing knowledge alone. Human resource competitivenes was being one of higher education responsibility to completed, to achieve great quality of their graduates. Hope that emerged from the students on the fulfillment of obligations towards their university becomes something that can not be separated from the quality of the graduates. Pyschological contract as a concept that can explain it, has not been widely studied in a higher education setting especially in Indonesia. The number of measuring instruments have its version on some theoretical models raises curiosity as to what is actually appropriate. Through the method of literature review, it was carried out a critical discussion of the components in the measurement of psychological contract at higher education institutions. The exposure in understanding the dynamics of inter-dimensional and determine the appropriate model based on the characteristics of each academic institution. At least, measurement of psychological contract used in higher education setting should be both of promissory (transactional) and non-promissory (relational) dimension. Surely, it's always need to adjusted with the conditions and situations relevantly in each institution. Therefore, it would be possible to bring various indicators in each of dimension.
\end{abstract}

Keyword: higher education, psychological contract

\section{PENDAHULUAN}

Salah satu tuntutan pemerintah terhadap institusi akademik adalah harus menghasilkan lulusan yang berdaya saing tinggi. Hal ini pun sebagai salah satu ukuran kualitas perguruan tinggi sehingga proses akademik yang dijalani oleh mahasiswa selama kuliah mestilah terjamin. Sejumlah dana yang dikeluarkan oleh mahasiswa harus seimbang dengan pemenuhan harapan akademik mereka selama menempuh pendidikan di suatu instutusi. Kewajiban institusi baik eksplisit maupun implisit yang dipersepsi oleh mahasiswa dengan dinamikanya terjelaskan dalam konsep psychological contract.

Sejumlah pembahasan tentang psychological contract sudah banyak ditemukan dalam beragam literatur dengan unit analisis individu terutama pada karyawan di lingkup industri dan organisasi. Psychological contract digunakan sebagai pendekatan yang dapat menjelaskan bagaimana karyawan mempersepsikan harapan dan pemenuhannya dari institusi atau organisasi dimana ia bergabung. Konsep ini menjadi salah satu yang berkontribusi untuk mempertahankan perilaku positif di 
organisasi (Coyle-Shapiro and Kessler, 2000; Robinson, 1996; Robinson and Morrison, 1995; Tekleab \& Taylor, 2000). Namun begitu, tidak cukup hanya di lingkup industri dan organisasi saja, dalam setting akademis pun konsep ini penting untuk dikaji mengingat betapa krusialnya pemenuhan harapan mahasiswa akan kualitas layanan yang diberikan oleh perguruan tinggi sebagai penyelenggara pendidikan.

Sejauh ini, pengembangan konsep mengenai psychological contract di setting perguruan tinggi masih terbilang jarang. Sebelumnya, memang telah ada beberapa penelitian yang dilakukan dalam setting ini namun generalisasi terapan penelitian memang kurang luas. Skup populasi cenderung terbatas pada suatu jenis institusi pendidikan saja. Perbandingan dengan ulasan yang menyeluruh tentang penelitian psychological contract di perguruan tinggi pun masih dinilai sedikit. Sehingga berpeluang menimbulkan kebingungan pendekatan mana yang tepat dipakai, model pengukuran mana yang sesuai untuk suatu kondisi di institusi. Oleh karena itu, dalam artikel ini akan diulas lebih lanjut mengenai perkembangan psychological contract di setting perguruan tinggi sehingga diharapkan dapat lebih memberikan gambaran secara jelas bagaimana penetapan pendekatan dan alat ukur yang sesuai.

\section{Perkembangan Penelitian Psychological Contract}

Kajian mengenai pscychological contract telah berkembang pesat dalam beberapa belas tahun terakhir yang diawali oleh pemikiran dari Rousseau (1989; 1995; 2001). Konsep ini berdasarkan social exchange theory, didefiniskan sebagai kontruksi mental yang bertanggungjawab atas persetujuan serah terima antara individu dengan pihak lain (Blau, 1964; Rousseau, 2001). Argyris (1960) menggunakan terminologi psychological work contract untuk menggambarkan kelekatan antara persepsi, harapan dan nilai dari kedua belah pihak (organisasi dan individu) terhadap hubungan pekerjaan. Literatur di awal kemunculannya, menggambar kan bahwa hubungan pekerjaan dibentuk oleh pertukaran keuntungan ekonomi juga sosial. Begitu pula dengan terminologi psychological contracts-transactional yang digunakan oleh Rousseau (1989, 1990) dimana pekerja lebih mengharapkan hubungan kerja dengan pertukaran antara jumlah waktu yang dihabiskan dalam bekerja dengan upah yang diperoleh. Konsep ini sangat tradisional yang menggambarkan bagaimana hubungan kerja antara industri dan pekerjanya.

Menurut Schein (1978) bahwa harapan antara organisasi dan individu tidaklah hanya soal pekerjaan dan upah saja namun serangkaian kewajiban, hak dan keuntungan yang diperoleh pekerja. Di sisi lain, pandangan mengenai psychological contract tidak hanya tercermin dalam kontrak kerja yang eksplisit, namun dapat pula secara implisit (Kotter, 1973). Hal ini pula yang memunculkan pandangan bahwa adanya ketidakpuasan pada pekerja datang dari adanya pengingkaran psychological contract yang mungkin tidak tertuliskan. Pemahaman bahwa psychological contract tidak hanya mengenai perjanjian tertulis namun juga melibatkan harapan implisit dari pekerja banyak dipakai oleh peneliti psychological contract lainnya (Holtz, 1978; Portwood \& Miller, 1976; Morrison \& Robinson, 1997). Di saat yang bersamaan pula, para praktisi di industri menjadi tidak banyak lagi menggunakan pendekatan hubungan kerja yang tradisional tadi. Hal ini dianggap 
menghabiskan waktu untuk membicarakan bentuk pertukaran tradisional tersebut. Dan tidak jarang pada akhirnya banyak terjadi penyimpangan karena adanya perang pasar yang semakin bersaing. Sehingga lebih banyak digunakan kerangka seperti psychological contract yang kita pahami saat ini, merefleksikan kebutuhan individu baik yang eksplisit, implisit bahkan harapan yang tidak disuarakan sekalipun, sebagai alternatif yang memudahkan.

Dalam psychological contract, dimensi yang tercakup di dalamnya cukup beragam. Diantaranya yang ditemukan dalam literatur adalah transactionalrelational (MacNeil, 1985; Millward \& Hopkins, 1998; Raja, Johns, \& Ntalianis, 2004; Robinson \& Rousseau, 1994; Rousseau, 1990), administrativeprofessional (Bunderson, 2001), transactional-relational-training

obligations (Coyle-Shapiro \& Kessler, 2000). Hanya saja, yang lebih banyak digunakan adalah dimensi transactional contract dan relational contract. Transactional contract adalah jenis kontrak jangka pendek yang dapat diukur dengan uang atau nilai ekonomi lainnya. Relational contract adalah jenis kontrak yang melibatkan aspek sosio emosional yang tidak selalu dapat diukur dengan uang. Pekerja melihat hubungannya dengan pemberi kerja sebagai bentuk hubungan jangka panjang sebagaimana manfaat/ keuntungan jangka panjang yang diperolehnya (pengembangan skill, peningkatan karir, dsb). Dalam seting kerja, individu dapat mempunyai salah satu jenis kontrak atau gabungan keduanya (Rousseau, 2000).

Sejalan dengan perkembangan kelilmuan, para peneliti mulai menyadari adanya ketimpangan dalam pemisahan dimensi transactional dan relational. Secara teoritis, ini dipandang sebagai dua hal yang saling berlawanan dari singlecontinuum konstruk daripada sekedar sebuah penggolongan tipe (Conway \& Briner, 2005; Rousseau \& McLean Parks, 1993). Sejak dua dekade yang lalu, juga disoroti bahwa kedua dimensi ini tidak mampu menggambarkan keseluruhan dari psychological contract dimana perubahan organisasi dan pekerjaan acapkali berubah (Guest, 2004; Rousseau, 1995). Oleh sebab itu, terminologi baru yang disebut balanced (hybrid) dari psychological contract telah mulai mewarnai psikologi industri dan organisasi.

Menurut Rousseau (1995,2000), di dalam balanced atau hybrid psychological contract $(P C)$ terkandung fleksibilitas yang lebih besar, performa yang lebih dinamis, kewajiban yang lebih tinggi terhadap pengembangan karir dan keterikatan kerja yang lebih lama dibandingkan dengan transactional dan relational contract. Menurut beberapa penelitian (Shore \& Barksdale, 1998; Rousseau, 1995; Janssens et al., 2003) yaitu (1) strong and balanced (kewajiban banyak dan beragam baik untuk perusahaan atau pekerja), (2) weak and balanced (kewajiban sedikit baik untuk perusahaan maupun pekerja), (3) employee-dominant (banyak kewajiban untuk pekerja, sedikir kewajiban untuk perusahaan), (4) employer-dominant (banyak dan beragam kewajiban bagi perusahaan dan sedikit kewajiban bagi pekerja), (5) balanced relational PC (menekankan pada kewajiban relasional antara pekerja dan perusahaan), dan (6) balanced transactional (menekankan pada kewajiban transaksional antara pekerja dan perusahaan). Menurut Ruokolainen (2016) bahwa tidak hanya tipologi tersebut yang mungkin muncul dalam organisasi karena beragam jenis kewajiban dialami dalam berbagai tingkatan 
seimbang/tidak seimbang dalam kombinasi yang beragam pula. Individu dengan segala kebutuhannya dan latar belakang pengalaman yang berbeda-beda akan mempersepsikan psychological contract dengan bervariasi pula. Hal ini akan menimbulkan kesenjangan antara harapan dengan persepsi mengenai pemenuhannya sehingga muncullah kajian mengenai psychological contract violation. Beberapa peneliti juga menyebutnya sebagai psychological contract breach yang dioposisikan dengan psychological contract fulfillment untuk mengulas bagaimana pemenuhan harapan dan realitas yang dipersepsi oleh pekerja. Sebuah violation terjadi ketika satu pihak dalam organisasi gagal untuk memenuhi kewajibannya, karena perjanjian dalam psychological contract muncul atas keyakinan dan persetujuan antara pihak (MacNeil, 1985). Violation dalam psychological contract berbeda dari tidak terpenuhinya harapan atas persepsi ketidakadilan. Pekerja biasanya memiliki harapan-harapan yang terlalu tinggi dari perusahaan dan seringkali tidak realistis untuk dipenuhi, ketika harapan ini tidak terpenuhi maka pekerja akan merasa kurang puas, kinerja menurun dan dapat pula mundur sebagai pekerja di perusahaan tersebut. Ketika terjadi violation dalam psychological contract, maka respon yang muncul lebih kuat. Reaksi yang muncul tidak hanya diidentifikasikan pada harapan yang tak terpenuhi akan reward atau benefit tertentu tetapi juga belief tentang penghormatan terhadap orang lain, codes of conduct dan pola perilaku lain yang berhubungan (Rousseau, 1989). Violation akan menimbulkan rasa marah dan mengerosi kepercayaan dalam hubungan antara manajemen dengan pekerja. Jika pegawai mempersepsi terjadi psychological contract violation/breach maka untuk menyeimbangkan keadaan, pekerja akan melakukan sesuatu seperti mengurangi kontribusi, atau menurunkan komitmen terhadap organisasi.

Dampak-dampak dari violation terhadap kecenderungan berperilaku pekerja sudah cukup banyak diteliti. Tingkat violation akan berkorelasi positif dengan turnover dan berkorelasi negatif dengan trust, kepuasan kerja dan keinginan untuk tetap bertahan di suatu organisasi. Sebaliknya, ketika pekerja menginterpretasikan harapan dan pemenuhannya sudah memadai maka tercermin dalam derajat fulfillment. Dalam hal ini, derajat pemenuhan yang dirasakan oleh pekerja akan dapat bervariasi sepanjang waktu. Misalnya di suatu waktu merasa bahwa lebih banyak dirasakan violation maka di waktu lainnya dapat saja pekerja merasa telah terpenuhi harapan akan kewajiban perusahaan (Rousseau \& Parks, 1993). Fulfillment akan menghantarkan pada kepuasan kerja dan komitmen terhadap organisasi (Guest et al., 1996; Robinson \& Russeau, 1994), organizational citizenship behavior (Robinson \& Morrison, 1994), perceived organizationa support (Coyle-Shapiro \& Kessler, 2000) dan performa kerja (Robinson, 1996). Ruokolainen, et.al (2016) dalam penelitian longitudinalnya menyatakan bahwa terdapat korelasi antara pemenuhan psychological contract terhadap employee well being yang diindikasikan melalui kepuasan kerja dan vigour at work. Pekerja yang merasakan keseimbangan dalam pemenuhan psychological contract akan merasakan semangat kerja yang lebih tinggi.

Penelitian Psychological Contract di Setting Perguruan Tinggi

Psychological contract memiliki beberapa karakteristik seperti dinamis, dapat berubah dari waktu ke waktu selama ada 
relasi antara pemberi kerja dan karyawannya. Sebagaimana telah dipaparkan diatas bahwa psychological contract merupakan mutual obligation berdasarkan harapan implisit maupun eksplisit. Harapan ini penting sehingga akan berdampak pada performa. Meskipun kontrak secara eksplisit jarang dibahas namun mengingat pentingnya aspek ini sebagai penentu bagi terbentuknya perilaku dan sikap karyawan maka kontrak eksplisit juga dinilai perlu untuk ditelaah. Disamping itu, menyadari bahwa tidak hanya lingkup perusahaan saja yang memerlukan terapan psychological contract, beberapa peneliti telah berusaha mencari pendekatan psychological contract di perguruan tinggi sebagai organisasi dalam konteks akademis.

Dalam konteks akademis yang akan ditelaah lebih lanjut bukanlah relasi antara institusi akademik (perguruan tinggi) dengan dosen atau pegawainya, tetapi lebih kepada relasi antara peguruan tinggi dengan mahasiswa sebagai penerima layanan. Benzoni, Rousseau \& Li (2006) berusaha menelaah bagaimana konsep psychological contract diterapkan pada hubungan yang dinamis antara fakultas dan mahasiswa doctoral di sebuah perguruan tinggi. Konsep ini diaplikasikan melalui penyesuaian-penyesuaian item berdasarkan alat ukur four-type psychological contract (Rousseau \& Tijoriwala, 1998) yaitu apakah tipe hubungan antara mahasiswa doctoral tersebut bersifat transactional, relational, balanced ataukah transitional. Item-item alat ukur dimodifikasi sehingga relevan dengan kondisi dan situasinya. Luaran yang dihasilkan dari penelitian ini pun berupa penggolongan tipe contract sesuai dengan self report survey yang diberikan oleh responden. Karena populasi dan sampel yang digunakan hanya pada satu institusi perguruan tinggi saja, maka hasil yang diperoleh dari penelitian ini menjadi tidak dapat digeneralisasikan lebih luas. Hal ini memang diakui sebagai keterbatasan dari penelitian ini.

Lalu, mengapa pendekatan tipologi yang dipakai? Kiranya hal ini memang disesuaikan dengan tujuannya misalnya menelaah bagaimana psychological contract type berkaitan dengan kualitas hubungan kolaborasi yang dijalin antar mahasiswa. Tipologi ini akan tepat digunakan manakala peneliti lebih ingin mengetahui pola relasi antar pihak tanpa mempertimbangkan bagaimana pemenuhan setiap harapan baik yang dinyatakan eksplisit maupun implisit. Melalui tipologi ini, akan nampak pula jenis psychological contract mana yang bersifat jangka panjang dan mana yang jangka pendek. Dan tentu bagaimana efektivitasnya sesuai dengan kebutuhan dan bentuk kerjasama yang dilakukan oleh kedua belah pihak. Misalnya ditemukan bahwa psychological contracttransactional akan lebih efektif ketika diterapkan pada kerjasama antar pihak yang berjangka waktu tidak lama dengan tujuan spesifik yang telah ditetapkan. Sedangkan tipe psychological contractrelational akan efektif diterapkan dalam situasi yang tidak terlalu menuntut pencapaian tujuan yang spesifik dan berbatas waktu, namun lebih ditujukan untuk hubungan yang bersifat jangka panjang seperti pembinaan berkesinambungan terhadap mahasiswa.

Sebagaimana sudah dijelaskan sebelumnya diatas, sejalan dengan waktu bersamaan pula dengan perkembangan pendekatan dalam psychological contract yang mengarah pada model pemenuhan (fulfillment) atau pengingkaran (violation) kewajiban kepada pekerja, sehingga hal tersebut dapat diterapkan pula di setting akademik. Untuk mengurai bagaimana pemenuhan kewajiban institusi kepada 
mahasiswa yang dalam hal ini dapat dikatakan sebagai pelanggan, bagaimana discrepancies antara persepsi tentang kewajiban dan pemenuhannya dan aspek mana saja yang patut mendapat perhatian. Kondisi ini akan mempengaruhi sikap dan perilaku akademik mahasiswa. Sebagai pertimbangan, patut pula diperhatikan bahwa variasi isi psychological contract tidak dapat digeneralisasikan pada seting pekerjaan yang berbeda (Conway \& Briner, 2005) sehingga selalu membutuhkan penyesuaian dan adaptasi berdasarkan situasi dan kondisi di pekerjaan tersebut.

Sebagaimana penelitian kualitatif yang dilakukan oleh Koskina (2013), psychological contract di perguruan tinggi merupakan relasi timbal balik antara mahasiswa terhadap dosen dan institusi (universitas maupun fakultas). Hal ini juga dinyatakan oleh Spies, et al (2010) dalam penelitiannya mengenai pengembangan instrumen psychological contract. Relasi antara mahasiswa terhadap dosen dan institusi ini bukanlah relasi yang bersifat sebentar saja. Di Indonesia khususnya, mahasiswa membutuhkan waktu setidaknya 2 tahun untuk menyelesaikan studi magister, sedangkan doktoral dan sarjana tentu mengambil waktu lebih lama yaitu sekitar 3-5 tahun. Sehingga, akan menjadi kurang komprehensif ketika yang digunakan dalam konteks ini adalah model tipologi psychological contract. Tipologi ini tepat digunakan manakala ingin melihat jenis mana yang efektif dalam situasi yang berbeda, juga ketika peneliti tidak memerlukan justifikasi sejauh apa pemenuhan kewajiban oleh salah satu pihak terhadap pihak lainnya.

Selain itu, lebih dalam jika ditinjau mengenai tujuan dalam proses akademik itu sendiri. Secara umum, kegiatan akademik diperuntukkan bagi pengembangan pengetahuan dan kemampuan seseorang dalam bidang ilmu tertentu sehingga dalam perjalanannya selalu membutuhkan pendampingan, penambahan wawasan dan proses diskusi yang mampu membentuk kematangan mahasiswa dalam berpikir. Meskipun ada capaian yang disasar melalui rangkaian evaluasi akademik, namun proses sepanjang pembelajaran perlu untuk diperhatikan. Proses pembelajaran yang memenuhi harapan menjadi penting, senada dengan itu bahwa persepsi mengenai situasi lingkungan belajar yang kondusif dan memuaskan terbukti menjadi salah satu prediktor keberhasilan dalam perkuliahan (Lizzio, Wilson \& Simmon, 2010).

Lebih dari itu, sebagai penyelenggara pendidikan tinggi maka goal akhirnya adalah mempersiapkan peserta didik menjadi anggota masyarakat yang memiliki kemampuan akademik dan profesional yang dapat menerapkan, mengembangkan dan menciptakan ilmu sesuai bidangnya. Oleh sebab itu, penting untuk dilihat bagaimana gap antara kewajiban (harapan) yang dipersepsikan oleh mahasiswa terhadap proses pembelajaran yang melibatkan peran dosen dan kebijakan institusi (fakultas ataupun universitas) dengan persepsi pemenuhannya. Tidak hanya dilihat bagaimana tingkat pemenuhannya saja, namun perbedaan dan kesenjangan yang terjadi di setiap aspek yang diukur. Karena dengan begitu, hal ini dapat menjadi umpan balik bagi institusi mengenai aspek mana saja dalam kaitannya dengan psychological contract yang dapat memperngaruhi sikap dan perilaku akademik mahasiswa. Bagaimana gap yang terjadi, positif ataukah negatif dan di area mana yang perlu diperhatikan lebih khusus. Jika dikaitkan dengan tujuan organisasi, maka hal ini akan menunjang pula identifikasi dan peningkatan capaian 
kerja yang diemban oleh institusi baik untuk keperluan peningkatan kualitas perguruan tinggi maupun pemenuhan key performance indicator yang menjadi penentu tingkat performansi institusi pendidikan.

Komponen apa yang tepat menggambarkan psychological contract di konteks perguruan tinggi ?

Setelah itu, lalu hal lain yang tidak kalah krusialnya adalah penentuan komponen dari psychological contract yang dipersepsi oleh mahasiswa di dalam konteks perguruan tinggi. Dalam beberapa penelitian yang dikaji mengenai pengembangan pengukuran psychological contract (Koskina. 2013; Spies, 2010), sebenarnya belum ditemukan sebuah konsep yang menjelaskan komponenkomponen psychological contract in student yang ajeg dan bersifat general, dapat diterapkan di institusi pendidikan di mana saja. Agaknya, hal ini memang tidaklah mudah dan begitu saja dapat dilakukan. Mempertimbangkan sistem dan kebijakan yang berbeda pada suatu negara dengan negara lain maka komponen apa saja yang signifikan menggambarkan psychological contract individu dalam suatu kelompok dapat saja berbeda. Sebagaimana yang diungkapkan oleh Conway \& Briner (2005) bahwa aspek di dalam psychological contract tidak dapat digeneralisasikan dalam setiap kondisi organisasi yang berbeda. Harus dilakukan penyesuaian-penyesuaian sehingga tepat menggambarkan keunikan dan kebutuhan setiap organisasi.

Psychological contract pada
mahasiswa dapat dilihat sebagai
pertukaran sesuatu yang bersifat material
(biaya) maupun non material (kuliah)
yang mereka keluarkan terhadap sesuatu
yang intrinsik (pengembangan dan
pembelajaran) maupun ekstrinsik (ijazah
kelulusan). Hal yang perlu diperhatikan

adalah bahwa di perguruan tinggi, selalu melibatkan contract antara mahasiswadosen dan universitas (fakultas), dan tentu saja dengan masuknya mahasiswa di perguruan tinggi maka ada harapan implisit yang perlu diangkat dalam menetapkan komponen psychological contract (Koskina, A. 2013). Setidaknya, elemen pembentuk psychological contract dapat mencerminkan hubungan yang bersifat transactional maupun relational. Transcational adalah hubungan pertukaran antara universitas dengan mahasiswa yang bersifat ekonomis, kewajiban materil terhadap mahasiswa. Sebagaimana Koskina (2013), mendefinisikan harapan akan transactional (promissory) terkait dengan hal-hal ekstrinsik mencakup janji akan adanya penggantian jumlah waktu kuliah, panduan belajar dan fasilitas. Sedangkan harapan akan relational (non-promissory) terkait dengan kemampuan mengajar, pendekatan ke mahasiswa, keluasan pengetahuan dan antusiasme. (Geall 2000; Sander et al. 2000; Voss, Gruber, and Smigin 2007; Willcoxson, Cotter, and Joy 2011).

Spies et., al (2010) mengemukakan bahwa dalam psychological contract pada seting akademis di mahasiswa harus pula mencakup relational contract yang menggali kewajiban institusi atas program pengembangan diri mahasiswa selama berkuliah seperti ekstrakulikuler, kemampuan berpikir kritis dan juga keprofesian. Hanya, memang mungkin saja indikator ini tidak begitu saja dapat diterapkan di semua jenis universitas. Oleh sebab itu, setiap komponen transactional maupun relational contract perlu disesuaikan dengan situasi, kondisi dan karakteristik dari setiap perguruan tingi. Sangat mungkin terjadi perbedaan antara indikator di institusi satu dengan yang lain, sehingga setiap pengukuran 
haruslah diadaptasi kembali sesuai dengan karakteristik masing-masing penyelenggara pendidikan tinggi.

\section{SIMPULAN}

Untuk mengkaji mengenai psychological contract dalam setting perguruan tinggi atas persepsi mahasiswa, maka dapat menginduk pada banyak penelitian psychological contract di industri dan organisasi serta meninjau pula beberapa pengembangan yang telah dikemukakan oleh beberapa peneliti sebelumnya dalam bidang akademik (Koskina, 2013; Spies et al, 2010) sehingga memperoleh kerangka psychological contract pada mahasiswa. Berdasarkan itu, maka persepsi mahasiswa atas kewajiban institusi pendidikan dapat dilihat dari dua dimensi besar yaitu transactional (promissory) yang melibatkan komponen fasilitas, jumlah waktu kuliah yang sesuai, panduan belajar yang lengkap dan relational (nonpromissory) seperti komponen pengembangan mahasiswa, keprofesian, kemampuan dosen dalam mengajar, relasi yang kondusif antara mahasiswa dengan dosen.

Saran

Diperlukan pengembangan dan adaptasi sesuai dengan kondisi di institusi masing-masing. Hal ini dikarenakan kedua dimensi tersebut dapat saja berbeda sehingga tidak dapat diterapkan untuk seluruh institusi pendidikan tinggi. Dengan begitu, penggalian kajian ini akan mungkin dilakukan dalam beragam jenis institusi pendidikan misalnya negeri, swasta ataupun di daerah yang berbeda. Sehingga diharapkan, diperoleh model alat ukur psychological contract yang mampu digeneralisasikan sesuai dengan jenis institusi pendidikan tertentu khususnya di Indonesia.

\section{DAFTAR PUSTAKA}

Argyris, C. (1960). Understanding Organizational Behavior. Homewood : IL : Dorsey Press.

Benzoni, Wade A. Kimberly, Rousseau, DM., and Li, Min.(2006). Managing Relationships Across Generations Of Academics: Psychological Contracts In Faculty-Doctoral Student Collaborations. International Journal of Conflict Management, Vol. 17 Iss: 1, pp.4 33

Blau, P. (1964). Exhange and Power in Social Life : New York : Wiley.

Bunderson, Stuart J. 2001. How Work Ideologies Shape The Psychological Contracts Of Professional Employees: Doctors' Responses To Perceived Breach. Journal of Organizational Behavior, Volume 22, Issue 7, 717-741.

Conway, N. and Brinner RB. (2005). Understanding Psychological Contracts At Work: A Critical Evaluation Of Theory And Research. Oxford University Press.

Coyle-Shapiro, Jacquelline A-M \& Kessler, I. (2000). Consequences of the Psychological Contract for the Employment Relationship : A Large Scale Survey. Journal of Management Studies, 37, 903-930.

Geall, V. 2000. The Expectations And Experiences Of First-Year Students At City University Of Hong-Kong. Quality in Higher Education 6, no. 1: 77-89. 
Guest, D. (1998). 'Is The Psychological Contract Taking Seriously?'. Journal of Organizational Behavior, 19, 649664.

Holtz, Jane L. (1978). Exploring the psychological contract over the life cycle. Dissertation Abstracts International, Vol 39(4-A), 2399.

Janssens, M., et al. (2003). Multiple types of psychological contracts: A SixCluster Solution.Sage Journal : Human Relations, Volume 56 no. 11, 1349-1378

Portwood, James D and Mill, Edwin L. (1976). Evaluating the Psychological Contract: Its Implications for Employee Job Satisfaction and Work Behavior. Academy Management Proceeding, 109-113.

Koskina, Aikaterini. (2013). What Does The Student Psychological Contract Mean? Evidence From A UK Business School. Journal of Higher Education, Routledge, Taylor and Francis Group : Vol. 38, No. 7, 1020-1036.

Kotter, J. (1973). The psychological contract. California Management Review 15, no. 3: 91-99.

Lizzio, A., Wilson, Keithia \& Simons, Roland. 2010. University Students' Perceptions of the Learning Environment and Academic Outcomes: Implications for theory and practice. Taylor Francis : Studies in Higher Education :Volume 27 : 2752

MacNeil, 1. R. (1985). 'Relational contract: What we do and do not know', Wisconsin Law Review,483525 .

Millward, Lyne J., and Hopkins, Lee J. (1998). Psychological Contracts, Organizational and Job Commitment. Journal of Applied Psychology. Volume 28, Issue 16, 1530-1556.

Morrison, Elizabeth Wolfe \& Robinson, Sandra L. (1997). When Employee Feel Betrayed : A Model How Psychological Contract Violation Develops. The Academy of Management Review. Volume 22 No 1, 226-256.

Nelson, L., Tonks, G. \& Weymouth, J. (2006). The Psychological Contract and Job Satisfaction: Experiences of a Group of Casual Workers, Research and Practice in Human Resource Management, 14(2), 18-33.

Robinson, S.L., Rousseau, D.M and Kraatz, Mattew S. (1994). Changing Obligation and The Psychological Contract : A Longitudinal Study. Academy of Management Journal. Volume 37 No 1, 137-152.

Raja, U., Johns, G., \& Ntalianis, F. (2004). The impact of personality on psychological contracts. Academy of Management Journal, 47, 350-367.

Robinson, S.L and Morrison, E.W. (1995). Psychological Contract and OCB : The Effect of Unfulfilled Obligation and Civic Virtue. Journal of Organizational Behavior, 16, 289198.

Rousseau, D.M. (1989). Psychological and implied contracts in organizations. Employee Responsibilities and Rights Journal 2, no. 2: 121-38 
Rousseau, D.M. (1990). New hire perceptions of their own and their employer's obligations. Journal of Organizational Behavior 11, no. 5: 389-400

Rousseau, D.M., and Parks, Judi Mc. Lean. (1993) The Contracts of Individual and Organization. Journal of Organizational Behavior, Volume $15: 1-43$.

Rousseau, D.M \& Tijoriwala, Snehal A. (1998) Assessing Psychological Contract : Issues, Altenatives and Measures. Journal of Organizational Behavior. Volume 19, 679-695.

Rousseau, D. (2001). Schema, promise and mutuality. Journal of Occupational and Organisational Psychology 74, no. 4: 511-41.

Ruokolainen, Mervi et al. (2016). Pattern of Psychological Contract and Their Relationship to Employee Well Being and In Role Performance at Work : Longitudinal Evidence from University Employees. The International Journal of Human Resource and Management. ISSN : 0958-5192

Sander, P., K. Stevenson, M. King, and D. Coates. (2000). University Students' Expectations Of Teaching. Studies in Higher Education 25, no. 3: 309-23.

Schein, E. H. (1978). Career Dynamics: Matching Individuals and Organizational Needs. AddisonWesley, Reading.

Shore, Lynn Mc Farlane \& Barksdale, K. (1998). Examining Degree Of
Balance And Level Of Obligation In The Employment Relationship: A Social Exchange Approach. Journal of Organizational Behavior, Volume 19, 731-744.

Spies, Alan R. (2010). Instrument to Measure Psychological Contract Violation in Pharmacy Students. American Journal of Pharmaceutical Education, 74 (6) Article 107.

Tekleab, AG \& Taylor, MS. (2000). Easing The Pain : Determinan and Effect of Psychological Contract Violations. Annual Meeting of Academic Management.

Voss, R., T. Gruber, and I. Smigin. (2007). Service quality in higher education. Journal of Business Research. Volume 60, no. 9: 949-59.

Willcoxson, L., J. Cotter, and S. Joy. (2011). Beyond the first-year experience. Studies in Higher Education . Volume 36, no. 3: 33152. 